\title{
THE MAIN PRINCIPLES OF THE LINGUISTIC THEORY OF NEOLOGY
}

\section{Kosovych O. V.}

\section{INTRODUCTION}

Modern linguistics considers language as a complex dynamic system, the direction and evolution of which are subject to the general laws of dialectics. The most active development of language is in the area of vocabulary, due to a number of its features in comparison with other linguistic levels, in particular, in the highest degree order of determining.

The vocabulary of the language is directly and closely connected with the history of the people, it reflects the views and beliefs of people, its outlook, reflected in the words of the moral evaluation of social phenomena, particularly the production, life and culture, and the like - in short, the vocabulary specifically reflects the diversity of human life.

Interest in the problems of neology in the works of scientists is determined by the particular function of the language innovation in the determination of the active development of language, the influence on the speech situation, the functioning of language under the influence of external factors and internal conditions.

Having emerged relatively recently, but developing and becoming stronger, neology is still somewhat controversial field of study in relation to its tasks and structural organization. Task definition of neology entails the identification of the range of problems associated not only with a versatile study of the fundamental concepts of neologism, but with the generalization of theoretical and practical knowledge and understanding of it as an independent field of linguistics.

In its formation neology as a scientific discipline has gone through several stages: from the first attempts of interpretation and identification of obscure words to the development of basic concepts of the science about a new word and the development of neography. The formation and flourishing of neology refers to the second half of the twentieth century. Despite numerous studies, that are doing today, there are unresolved and debatable many of the issues associated with the understanding of the term neologism, the nature and essence of lexical innovation, and with the methods of study, methods of classification and means of lexicographical fixation of new words. 
Today, the term neology is conceptualized in a broader sense than before, namely as the science of the new phenomena of all levels of the linguistic system, not just of its lexical subsystem. This approach contributes to the formation of a new vector of development of neological field of linguistics - the study of neologisms as units of various language levels and inter-level approach to the language system. In some works the category of neologism is projected on all language levels. This approach greatly expands the concept of neologism, bringing it to a qualitatively new level. From our point of view, the innovation is a phenomenon of language, covering all its levels: phonetic (the emergence of new variants and variants of pronunciation), morphological (development of a new formative and word forms), syntax (the variance and the emergence of new syntaxes), etc., because the recognition of consistency as the main ontological characteristics of the language system requires a comprehensive study of innovations, which could contribute to the manifestation of inner, organic conditions and the interrelationship of different structural units in the process of neologization. It should be note also that the study of the process of neologization in terms of the interaction of phonetic, lexical, word formation, phraseological, grammatical levels deepens the already existing ideas about neologisms, promotes the formation and development of a new direction in science, and the attention is is drawn to the fact that a neologism is a phenomenon of the language system.

The emergence of new words (meanings, combinations) is not in direct and only connection and changes in the world of realities. Innovation formation is influenced by both social and intralingual stimuli. This should be considered when analyzing the nature of the lexical and phraseological innovations in the structure of language.

The idea of a "new word" for several centuries has undergone a transformation and significant expansion. New words were understood at first only as loan-words. Participating in the vocabulary of the language, lexical innovation, stimulate word-formation and semantic processes that characterize the modern French language, and also provide an opportunity to identify the most important trends of its development.

\section{The principles of the linguistic theory of neology}

Language as a dynamic system is characterized by the ability to continuous improvement and regular enrichment, thus differing from extinct languages. The history of the language can, from this point of view, be regarded as the history of neology, understood as movement, evolution of language, and, in particular, B. Quemada notes as follows: 
"Une langue qui ne connaîtrait aucune forme de néologie serait déjà une langue morte, et l'on ne saurait contester que l'histoire de toutes nos langues n'est, en somme, qu'une histoire de leur néologie",.

In a system of any language its lexical layer shows the most pronounced tendency for constant changes and updates. Renovation of the vocabulary may manifest itself in various ways, but the most dynamic way of the language vocabulary renovation is the formation of new words.

Although the study of neology is a relatively new linguistic direction, it has already achieved significant results, which are presented in the works of scholars of different linguistic schools. In France, the first prerequisite to the study of the neological process arose in connection with the regulatory pressure on the French language, the beginning of which is marked from the XVII-th century. In this period, special attention was paid to the lexical layer of language, and any modification of any form of innovation was subjected to merciless criticism: linguistic innovation was seen as unnatural in the manner of communication, oddities, or even abuse, ignoring, as noted by J.-F. Sablayrolles, "language superfluous, a symptom of posturing, with some precise description" and of novelty affectation (unnatural) ${ }^{2}$. At the beginning of their appearance neologisms drew criticism because purists of language considered them useless or ridiculous. The opposite attitude, which supported the process of the vocabulary enriching of the French language, is associated with the movement of "Les Précieuses". In the online version of the explanatory dictionary "Le Petit Larousse" this movement is defined as "femmes de la société aristocratique française du début du XVIIe siècle qui entreprirent de raffiner les manières et le langage" (women who have shown new and refined attitude to the sense of novelty, as well as sophisticated language) ${ }^{3}$. This social and literary movement was originated in aristocratic salons, which the most famous are salons of the Marquise Rambouillet, Catherine de Vivonne. Along with this, it should be noted the play of Moliere "Les Précieuses

${ }^{1}$ Quemada B. A propos de la néologie. Paris: CILF, La banque des mots (№ 2), 1971. P. 175.

2 Sablayrolles J.-F. Néologismes: Une typologie des typologies. Cahiers du CIEL, 1996. P. 26. URL: http://www.eila.univ-paris-diderot.fr/recherche/clillac/ciel/ cahiers/1996-1997; Sablayrolles J.-F. La néologie en français contemporain. Examen du concept et analyse de productions néologiques récentes. Paris: Honoré Champion, coll. «Lexica», 2000. №4. p. 46-48.

${ }^{3}$ Larousse. URL: www.larousse.fr 
ridicules", which also represents a caricature of women of the movement "Les Précieuses".

The first evidence of the appearance of lexical units, formed from the Greek confix neos "new" and logos "word" is marked: néologisme in 1734 in the "Introduction générale à 1 étude des sciences et des belles lettres, en faveur des personnes qui ne savent que le François" (AntoineAuguste Bruzen de la Martinière) [http://www.cnrtl.fr] and néologie in 1757 in the "Supplément du dictionnaire critique de la langue française de J. F. Féraud" during various social changes, scientific progress, the role of the witness of them was played by language. One of the first dictionaries "Le dictionnaire à l'usage des beaux esprits de ce siècle, avec 1 éloge historique de Pantalon - Phebus" (the abbé Guyot Desfontaines, XVIII century ${ }^{5}$ ) specifies a "new word" primarily as strange and unknown, contrary to the notion of "neology - speech activity (action), which consisted in the formation and the use of new lexical units.

F. Domerg, in his turn, offers the following definitions for the two terms: "La néologie est l'art de former des termes nouveaux pour des idées nouvelles ou mal ou rendues. Le néologisme est la manie d employer des mots nouveaux sans besoin ou sans goût" 6 .

Analyzing these concepts, the scientist noted the "positive definition" of the first term, in relation to the "negative definition" of the second term. In this regard, the researcher distinguishes three aspects in the definitions of the terms: 1) an abstract plan/plan abstrait, expressed with a noun art - art, in its classical sense, and which is opposed to the medical term manie - mania, in the pejorative meaning; 2) the transition to a more concrete plan (plan concret) with the help of the verb former, indicating an active role in the formation of the new vocabulary that it is impossible to mark on the verb employer; and 3) two objects defining two alternatives that reflect the goal (but) of the science of new words (pour des idées nouvelles ou mal ou rendues) in relation to the lack of purpose of a new word (sans besoin ou sans goût).

In 1762, in the fourth edition of its dictionary of the French Academy has tried to clarify and distinguish these concepts. According to the dictionary definition, the terms "neologism" and "neology" refer to:

4 Bibliothèque Numérique TV5 Monde. URL: https://bibliothequenumerique. tv5monde.com

${ }^{5}$ Gallica. URL: https://gallica.bnf.fr.

${ }^{6}$ Persée. URL: https://www.persee.fr/doc/linx_0246-8743_1982_num_7_1_968. 
néologisme: habitude de se servir de termes nouveaux ou d'employer les mots reçus dans des significations détournées; ce mot se prend depuis toujours en mauvaise part. La néologie est un art, le néologisme est un abus;

néologie: mot tiré du grec, qui signifie proprement invention, usage, emploi de termes nouveaux. On s'en sert, par extension pour désigner l'emploi de mots anciens dans un sens nouveau?.

In XIX-th century, the development of lexicography was noted, as well as intensive publication lexicographic sources. In the second half of the XIX-th century lexicographical study of the concepts of „neology” and "new word" was based on three dictionaries:

1) French Dictionary (1863-1872) E. Littre;

2) The universal dictionary of the nineteenth century (1866-1876) by P. Larousse and 3) The general dictionary of the French language (18901900) by A. Hatzfeld and A. Darmesteter.

The concept of neology is heterogeneous and is developed on the basis of the above dictionaries that are specific to each lexicographer and it is defined by different study criteria of the term "neologism" and "neology":

1) the study of the concepts as historical categories in the dictionary of E. Littre (1801-1881):

néologisme - 1) habitude et affectation de néologie; 2) mot nouveau, ou mot existant employé dans un sens nouveau ${ }^{8}$;

néologie - emploi de mots nouveaux ou d'anciens mots en un sens nouveau?.

About the neologism as a historical concept, the Romanian lexicology E. Coseriu said: "les locuteurs ont conscience que certains éléments sont "plus anciens" ou "plus récents", mais ils ne manifestent pas cette conscience en parlant avec ces éléments, dans le langage primaire, la ils manifestent en parlant sur eux, dans le métalangage, C'est-à-dire que aussitôt, cessant d'être simplement des "locuteurs", ils these [...] "linguistes" et adoptent un point de vue historique"

2) the encyclopedic focus of the study of terms in the dictionary of P. Larousse:

${ }^{7}$ Le Dicopathe. URL: https://www.dicopathe.com

${ }^{8}$ Dictionnaire Littré. URL: https://www.littre.org/definition/néologisme.

${ }^{9}$ Dictionnaire Littré. URL: https://www.littre.org/definition/néologie.

10 Coseriu E. Synchronie, diachronie et histoire. (réed.) 2007. URL: http://www.revue-texto.net/Parutions/Livres-E/Coseriu_SDH/Sommaire.html 
néologisme - tout mot de création récente ou emprunté depuis peu à une autre langue ou toute acception nouvelle donnée à un mot ou à une expression qui existaient déjà dans la langue;

néologie - ensemble des processus de formation de nouvelles unités lexicales $^{11}$.

3) logical-rhetorical approach of the dictionary of A. Hatzfeld and A. Darmesteter:

néologisme - 1) emploi de mots de création nouvelle, ou de mots anciens pris dans une nouvelle acception (syn. néologie); 2) mot de création nouvelle, ou pris dans une nouvelle acception;

néologie - emploi de mots de création nouvelle, ou de mots anciens dans une nouvelle acception ${ }^{12}$.

The purpose of these dictionaries, however, is defining of the general state of language in the process of neologization, and a number of other lexicographic studies lead to the end of the XIX-th century to the gradual consolidation of the linguistic status of the concepts of "new word" and "the science of new words" (neology).

The formation of the linguistic theory of neology is observed only in the second half of XX-th century (1960-1970) in the process of consolidating the concepts of "neology" and "neologism" as the status of scientific and actual values. The designation of the concept of "neology" remains controversial in the international linguistic tradition and is limited to the representation of neologisms as new lexical units without specifying, however, the signs of novelty detection of the lexical units are possible. A number of theoretical aspects of the study of new lexical units are affecting and are using only in close relationship and interaction with the practical tasks (preparation of the lexicographic sources). However, a greater number of theoretical studies in the field of science of new words belong to French and Russian researchers.

In the electronic version of modern dictionary lexical unit neologism (from greek neo and. logos - word) is defined as 1) new word and expression created to denote new objects or to express new concepts. Neologisms include also loan-words; 2) new words and expressions, the singularity of which is clearly felt by native speakers ${ }^{13}$.

S.I. Alatortseva defines the term "neology" as:

${ }^{11}$ Larousse P. Grand dictionnaire universel du XIXe siècle (1866-1876). URL: https://books.openedition.org/pum/10510.

12 Dictionnaire SensAgent. URL: http://dictionnaire.sensagent.leparisien.fr/ Néologie/fr-fr/.

${ }^{13}$ Modern dictionary, 2003. URL : https://slovar.cc/rus/bse/507974.html. 
1) the science of new words;

2) a set of neologisms ${ }^{14}$.

In the researches E.V. Marinova uses the synonym of the term "neology": "currently neology (less neologistic) is called relatively a young branch in the linguistics that studies the ... neologisms. And the range of neologisms is called neology or neological vocabulary"15.

Analyzing new words and phrases in the German language, E.V. Rosen distinguishes two types of neology: necessary and excess. With the concept of necessary neology, the author relates: 1) all new categories that appear along with language innovations; 2) the entry of neology in the system of linguistics and its formation as an integral part of lexicology ${ }^{16}$.

The process of neologization in the language is discussed in the studies of V.G. Gak from the position of the 5 main stages, which determine the main objectives of the science of new words:

1) the designation of a new lexical units, the new meanings of lexical units and new combinations of lexical units;

2) the studying of the reasons for the formation of new words;

3 ) identification of strategies of neologisms word formation;

4) the studying of criteria for the classification of neologisms;

5) the fixing of neologisms in general and special dictionaries that tells about the important task of neology, which is determined by the need to study neologism not only as a fundamental object of neology, but neography ${ }^{17}$.

The development of the theory of neology is quite closely associated and occur in conditions of:

1) development of a new theory of words and a multilateral study of the boundaries of the phenomenon of "new", "novelty", "innovation" in lexicology. In modern neology the concept of neologism is interpreted as

${ }^{14}$ Алаторцева С. И. Проблемы неологии и русская неография: автореферат дис. ... доктора филол. наук. СПб., 1999. 40 с. URL: http://www.dissercat.com/ content/problemy-neologii-i-russkaya-neografiya. C. 31.

15 Маринова Е.В. Основные понятия и термины неологии. Языки профессиональной коммуникации: материалы междунар. науч. конф. Челябинск: Энциклопедия, 2003. С. 243.

16 Розен Е.В. На пороге ХХІ века. Новые слова и словосочетания в немецком языке: учебное пособие. М.: Менеджер, 2000. С. 23.

${ }^{17}$ Гак В.Г. О современной французской неологии. Новые слова и словари новых слов. Л.: Наука, 1978. С. 37-52. URL: http://www.neolexiling.narod.ru/ Material/Gak_franz_neol.htm. C. 23-24. 
follows: as a new lexical unit, the new meaning of the lexical units and the new combined of lexical units. It is connected first of all with a thorough understanding and interpretation of the concept of "new". Along with the definition of the word "neologism" as a generic term for any type of neolexeme many researchers use the term "innovation" which stands for "innovation", "any lexical-semantic innovation"18.

The word "innovation" is considered as generic for a wide range of concepts represented by the terms "neologism", "innovation", and "occasionalism", "individually-author's word".

2) appearance in linguistic theory of the variety of classifications and typologies of the new language formations;

3) expansion of the vocabulary studies of a new word. For the concept of neology the studying of linguistic and extralinguistic factors influencing the formation of new lexical units and their subsequent use in speech is of the utmost importance, for example: the development of society, dynamic political processes, the expansion of cultures, the development of mass media, Europeanization. These factors are a prerequisite to the active enrichment and updating of the vocabulary of the language with new lexical units.

Enrichment of vocabulary is a natural process, because language as a social phenomenon reflects all the changes taking place in society, and the emergence of new words is a clear sign of strong vitality of the language. The history of the language can, from this point of view, to be considered as the history of neology.

V.G. Gak notes that as an example of the evolution and progress of language increase the complexity of its vocabulary in the process of the development of civilization and complication of social life ${ }^{19}$.

This is evidenced by the considerable number of works of French scientists in the twentieth century, in which they consider features of constructing of the theory of neologism (Matore 1952; Riffaterre 1953; Rheims 1969; Guilbert 1973), the main propositions of the theory of semantic and lexical neology (Doppagne 1971; Bastuji 1974; Guilbert 1975; Goosse 1975; Rey 1975; Dougnac 1982; Quemada 1993), the problem of neologism as an object of neography (Gaudin, Guespin 2000; Sablayrolles 2000), as evidenced by "speaking" names of these works

18 Современный русский язык. URL: https://biblio-online.ru/viewer/ 0BF1BCE7-A20E-4A92-8B3C-E74660A844EF/sovremennyy-russkiy-literaturnyyyazyk-praktikum\#page/82.

${ }^{19}$ Гак В.Г. Языковые преобразования. М.: Языки рус. культуры, 1998. 768 с. 
(see bibliography). We find also similar ideas in Russian scientists (Gak 1998; Lopatnikova 2001; Skuratov 2006; Tchekalina 1998 and others).

In the XXI-th century results on the study of the phenomenon of neology from the cognitive position is reflected are studied by French and Romanian scientists in which the problem of lexical innovation is investigated (Depecker 2001; Broglie 2002; Sablayrolles 2003; Dincă 2010), the problem of categorical and semantic neology (Pruvost, Sablayrolles 2012; Lecolle 2012), the problem of neologism as an object of neography (Sablayrolles 2006; Klein 2006; Boulanger 2008), features of political innovation (Tournier 2002; Mady 2005).

In the works of J.-F. Sablayrolles and J. Pruvost it is emphasized that neology is not a secondary phenomenon of language in terms of quantity and quality. According to the researchers, the concept of "neology" is determined by identifying of lexical units, the notion of novelty and the perception of novelty, and it is investigated mainly in accordance with the five fundamental categories:

1) the process of formation of new words;

2) theoretical and practical study of the language innovations;

3) purposeful activity of the state organizations with the purpose of tracing the process of the emergence, identification, and distribution in everyday speech, as well as inclusion in the dictionary of new lexical units;

4) identification of areas of special terminological orientation, which require important lexical contribution in order to overcome the shortage of vocabulary;

5) the compilation of lexicographic sources (according to J. Boulanger) ${ }^{20}$.

According to Y.A. Vorontsova and V.P. Spiridonova [Vorontsova 2016; Sviridonova 2013], the active process of the French language neologization, which is observed in the last decade, has attracted considerable interest among specialists. During the period of technology processes in the world, active political processes and various modifications, large-scale phenomena in the international and world level the process of language enrichment is continuous. Dynamic spheres of human activity, where there is an avalanche flow of neolexemes, with the subsequent replenishment of the linguistic terminology fund, are

20 Boulanger J.-C. Chronologie raisonnée des bibliographies de la néologie précédée de quelques miscellanées. Neologica. Paris: Editions Garnier, 2008. № 2. PP. 185-199. 
considered to be information technology, politics, sports, sociology, psychology, economics, etc.

Neology is played mainly a social role, due to the fact that the new emerging reality needs to be named, arranged from the standpoint of language, linguistics. Democratization and internationalization are main trends of the evolution of modern language, there is clear interaction between language-society - a condition especially important for the formation (appearance) of neologisms.

\section{Neologism as an object of linguistic studies in romance philology}

The modern concept of neologism - a fundamental aspect of research in the theory of science of new words - is a versatile understanding of new words as new lexical units, due to:

1) complex nature of language phenomena; 2) broad representation and diversity of views about the concept of "new" and 3) understanding of the concept of "neologism" as a socio-historical category.

As noted by F. Gaudin and L. Guespin, the concept of "neologism" is not a psycholinguistic concept, revealed a novelty that a person experiences when meeting neolexeme. On the contrary, this is a language category which implies first and foremost that meeting with a new word makes the speaker having sense of new ${ }^{21}$.

In proceedings of neology there are many different definitions of the term "neologism", and probably for this reason, this concept is interpreted and classified in different ways.

In studies of L. Guilbert (Guilbert 1973) a new word is interpreted from the point of view:

1) of the form because the neologism is a linguistic sign, including meaning side and the side that it means. They change together in the process of formation of new lexemes, even if the changes relate to the morphology of the term or only its meaning;

2) of the meaning, due to the fact that neological formation is not mostly a minimum unit of meaning, and based on the combination of more basic elements existing in the concrete language. The formation of new unit in this case is the result of the ratio of such minimum elements;

3 ) of the functioning: the creation of a neologism cannot be dissociated from speech (discourse) entity-creator integrated into society.

${ }^{21}$ Gaudin F., Guespin L. Initiation à la lexicologie française. De la néologie aux dictionnaires. Bruxelles: Ed. Duculot, 2006. P. 248. 
According to the French lexicologist J.-F. Sablayrolles, proposed by L. Guilbert structure of the new word interpretation led to the definition of traditional schemes of classification of neologisms, which includes: formal neologism (new meaning always born with a new signified) ${ }^{22}$, semantic neologism (existing meaning takes a new signified) ${ }^{23}$, as well as loan-word, as a special subclass of neologisms.

However, the existence of a diversity of typologies of neologisms in the works of French researchers, supplementing or modifying the classical trichotomy: formal neologism - semantic neologism - loanword is due mainly to the choice of classification criteria.

A number of researchers classify neologisms in accordance with the language needs, communication situation (communication), area of occurrence or by their function in discourse.

In the works of A. Goosse typology of the innovations is considered in accordance with the criterion of their categorization based on categorization theory of F. Gaudin and L. Guespin, which implies the classification of neologism into various categories. As A. Goosse ${ }^{24}$ notes, a new word can be both a loan-word and derivative, and this problem is a result of the fact that multiple models can contribute to the formation of the same neologism. During the study of this problem A. Goosse, that was based on the aforementioned classic trichotomy of the innovations, highlights the dichotomy of "formal neologism and semantic neologism" placing the loan-words into individual place as a subclass of formal neologisms.

Some researchers, relying on the criteria of formation of lexical innovations, retain the traditional structure of trichotomy, complementing it with a new word-building elements:

J. Dubois, along with the classical trichotomy singles out abbreviations (Dubois 1962), A. Goosse marks out abbreviations and the new use of words (Goosse 1975), J. Tournier distinguishes morphological neologisms (reduction by apheresis, apocope, abbreviation) (Tournier 1985), R. Arnaud contrasts the classic methods

${ }^{22}$ Sablayrolles J.-F. La néologie en français contemporain. Examen du concept et analyse de productions néologiques récentes. Paris: Honoré Champion, coll. «Lexica», 2000. № 4. P. 43.

${ }^{23}$ Sablayrolles J.-F. La néologie en français contemporain. Examen du concept et analyse de productions néologiques récentes. Paris: Honoré Champion, coll. «Lexica», 2000. № 4. P. 45.

24 Goosse A. La néologie française aujourd'hui. Conseil International de la langue française. Paris, 1975. P. 73. 
of formal education of neologisms by prefixation, suffixation and compounding with the Frenglish hybrids (Arnaud 1972) and other new forms, in particular games. According to P. Guiraud (Guiraud 1976), the essence of gaming forms is the inclusion in the native lexical unit of the new "secret" message, the new meanings by modifying the shape of the original sign.

A number of researchers rely on semantic criteria of neologisms classification by modifying the classical scheme.

M. Riffaterre distinguishes words that re-appear (and which are not archaisms) (Riffaterre 1953), L. Guilbert marks out sociological neologisms (Guilbert 1973), Cl. Hagège marks out spontaneous neologisms (néologismes spontanés), terms (néologismes réfléchis) and authorial neologisms (Hagège 1983), A. Walter gives the verlan (one of the types of argo) a separate category, on one level with new meanings (Walter 1989), J. Rey-Dubow identifies neologisms, revealing semantic innovation, scientific words and loan-words (Rey-Debove 1987).

However, the most comprehensive and well-established typology, reflecting both semantic and word-formative additions to the traditional trichotomy is the classification of J.-F. Sablayrolles and J. Pruvost, presented in the work "Les neologisms" (2012). In this classification, the authors identify:

1) inner matrix (inner form), which includes:

1. morpho-semantic neologisms formed by:

1.1. word combination (construction),

1.2. affixation (prefixion and suffixation),

1.2.1. reverse derivation,

1.2.2. parasynthesis,

1.3. compounding,

1.3.1. synapses,

1.3.2. quasi-morphemes,

1.3.3 telescope words,

1.4. simulation and deformation,

1.4.1. onomatopee,

1.4.2. graphic game,

1.4.3. paronymy,

2. syntactic and semantic neologisms formed by:

2.1 changes of the word function,

2.1.1. conversion,

2.1.2. syntactic combinatorics (compatibility),

2.1.3. lexical compatibility,

2.2 changing of the word meaning, 
2.2.1. metaphors,

2.2.2. metonymy,

2.2.3. other means of expression,

3. morphological neologisms formed by:

3.1. reduced forms,

3.1.1. truncation,

3.1.2. abbreviations,

4. semantic-pragmatic neologisms ${ }^{25}$.

2) external matrix - loan-words, which serve the formation of new words outside of the language system, in the conditions of their import from other language systems, foreign languages, living or ancient. As noted by J.-F. Sablayrolles and J. Pruvost ${ }^{26}$, at the same time loan-word moves with new concrete or an abstract reality that specifies, and it adapts (assimilates) to a new language system.

Currently, the formation of neologisms by means of lexical units borrowing from other language systems are most often associated with external factors - a modern strategy to strengthen global relations.

In the study the G. Matore the classification of new words is based on the principle of the need to create new lexical items, which determines their separation by the author on necessary mandatory neologisms (néologismes nécessaires, obligatoires) ${ }^{27}$, i.e., created in accordance with the strong need of the things nomination, ideologies, concepts, new technologies and luxurious, refined neologisms (néologismes de luxe), formed without a real need, but depending on fashion or general trends (e.g. a trendy word, which is in the French language neologism created in 2017 - la selfie $)^{28}$.

In accordance with the criteria for attributing the neologism to a particular situation of communication A. Hermanns distinguishes between "primary neologisms" (néologismes primaires), nominating new concepts and "translated neologisms" (néologismes traductifs), which are formed in the process of translation in the absence of an equivalent in the target language [Hermanns 1999, p. 37].

${ }^{25}$ Pruvost J., Sablayrolles J.-F. Les néologismes (2-e édition). Paris: PUF, 2012. P. 117.

${ }^{26}$ Pruvost J., Sablayrolles J.-F. Les néologismes (2-e édition). Paris: PUF, 2012. P. 115.

${ }^{27}$ Matoré G. Le néologisme: naissance et diffusion. Le français moderne. № 2. Paris: CNRS, 1952. P. 88.

${ }^{28}$ Le Petit Robert de la langue francaise 2015. URL: http://www.lerobert.com. 
In the study it should be note that the above typology of neologisms based on three main criteria:

1) criteria of categorization, which allows to distinguish "formal neologism" - "semantic neologism";

2) derivational criterion, which helps to identify the main characteristics of neologisms word-formation;

3) semantic criterion, which allows to reveal the semantic and pragmatic potential of the new lexical units, as well as loan-words, as a special subclass of neologisms.

In combination, these criteria most fully reveal the functionality of the new words and allow to reflect different levels of correlation and interaction of its structural (formal), semantic-pragmatic and functional characteristics.

\section{CONCLUSIONS}

In the study of the fundamental works on the theory of neology we came to the conclusion that the peculiarities of the linguistic theory of neology is due to several basic principles:

1) definition and versatile interpretation of "neology" and "neologism";

2) perception and interpretation in romance Philology of the terms "new", "innovation", "new word";

3) expansion of ideas about the neologism, not only as a fundamental category of neology, but of neography.

The concept of "neologism" gets mixed interpretation, which could be considered as linguistic (lexical) unit, as a speech (stylistic, occasional, individually-author's) unit. This is due to a broad understanding of the concept of "new" and the understanding of the concept of "neologism" as a socio-historical category.

Attention of researchers is focused on the consideration of intralanguage and non-linguistic factors affecting the formation of new concepts and realities, as well as their subsequent redistribution and use in speech, for example: the development of society, social and cultural change, media development, intense public and political life, the convergence of cultures, globalization. All these factors contribute to a particularly dynamic enrichment of the language of the new units.

Along with this, current trends in the study of the new words are of special importance for the theory of neology. This problem is considered in several scientific concepts in direction with the three main areas of study:

- typological study of neologisms; 
- study of the concept of "neologism" from the standpoint of cognitive linguistics and cultural linguistics;

- integrative approach to the study of neologisms, taking into account not only linguistic data but also data from other areas of science, such as sociolinguistics, psycholinguistics, ethnolinguistics, cultural studies, indicating active processes of socialization. In course with the integrative areas of study the classic problem of the study of language as object language extends to the level of his research as a concept of national culture.

\section{SUMMARY}

The article deals with the formulated the basic theoretical principles of the linguistic theory of neology. Basic concepts of the theory of neology and its terminology are considered. It has been determined that the renovation of the vocabulary may manifest itself in various ways, but the most dynamic way of the language vocabulary renovation is the formation of new words. The article emphasizes on the attention of researchers that is focused on the consideration of intra-linguistic and non-linguistic factors affecting the formation of new concepts and realities, as well as their subsequent redistribution and use in speech (the development of society, social and cultural change, media development, intense public and political life, the convergence of cultures, globalization etc.). Attention is drawn to the fact that in proceedings of neology there are many different definitions of the term "neologism", and probably for this reason, this concept is interpreted and classified in different ways. Current trends in the study of the new words are of special importance for the theory of neology. This problem is considered in several scientific concepts in direction with some main areas of study: 1) typological study of neologisms; 2) study of the concept of "neologism" from the standpoint of cognitive linguistics and cultural linguistics; 3) integrative approach to the study of neologisms, taking into account not only linguistic data but also data from other areas of science, such as sociolinguistics etc.

\section{REFERENCES}

1. Алаторцева С.И. Проблемы неологии и русская неография: автореферат дис. ... доктора филол. наук. СПб., 1999. 40 c. URL: http://www.dissercat.com/content/problemy-neologii-i-russkayaneografiya. 
2. Гак В.Г. О современной французской неологии. Новые слова и словари новых слов. Л.: Наука, 1978. С. 37-52. URL:http://www.neolexiling.narod.ru/Material/Gak_franz_neol.htm.

3. Гак В.Г. Языковые преобразования. М.: Языки рус. культуры, $1998.768 \mathrm{c}$.

4. Маринова Е.В. Основные понятия и термины неологии. Языки профессиональной коммуникации: материалы междунар. науч. конф. Челябинск: Энциклопедия, 2003. С. 243-247.

5. Розен Е.В. На пороге XXI века. Новые слова и словосочетания в немецком языке. М.: Менеджер, 2000. 192 с.

6. Современный русский язык. URL: https://biblio-online.ru/ viewer/0BF1BCE7-A20E-4A92-8B3C-E74660A844EF/sovremennyyrusskiy-literaturnyy-yazyk-praktikum\#page/82.

7. Bibliothèque Numérique TV5 Monde. URL: https://bibliothequenumerique.tv5monde.com.

8. Boulanger J.-C. Chronologie raisonnée des bibliographies de la néologie précédée de quelques miscellanées. Neologica. Paris: Editions Garnier, 2008. №2. P. 185-200.

9. Dictionnaire Littré. URL: https://www.littre.org/definition/.

10. Dictionnaire SensAgent. URL: http://dictionnaire.sensagent. leparisien.fr/Néologie/fr-fr/.

11. Coseriu E. Synchronie, diachronie et histoire. (réed.) 2007. URL: http://www.revue-texto.net/Parutions/Livres-E/Coseriu_SDH/Sommaire. html.

12. Gallica. URL: https://gallica.bnf.fr.

13. Gaudin F., Guespin L. Initiation à la lexicologie française. De la néologie aux dictionnaires. Bruxelles: Ed. Duculot, 2006. 249 p.

14. Goosse A. La néologie française aujourd'hui. Conseil International de la langue française. Paris, 1975. P. 73.

15. Larousse P. Grand dictionnaire universel du XIXe siècle (18661876). URL: https://books.openedition.org/pum/10510.

16. Larousse. URL: http://www.larousse.fr/

17. Le Dicopathe. URL: https://www.dicopathe.com.

18. Le Petit Robert de la langue francaise, 2015. URL: http://www.lerobert.com.

19. Matoré G. Le néologisme: naissance et diffusion. Le français moderne. № 2. Paris: CNRS, 1952. P. 87-92.

20. Modern dictionary, 2003. URL: https://slovar.cc/rus/ bse/507974.html.

21. Quemada B. A propos de la néologie. Paris: CILF, La banque des mots (№ 2), 1971. P. 137-156. 
22. Persée. URL: https://www.persee.fr/doc/linx_0246-8743_ 1982_num_7_1_968.

23. Pruvost J., Sablayrolles J.-F. Les néologismes (2-e édition). Paris: PUF, 2012. $127 \mathrm{p}$.

24. Sablayrolles J.-F. Néologismes: Une typologie des typologies. Cahiers du CIEL, 1996. P. 26. URL: http://www.eila.univ-parisdiderot.fr/recherche/clillac/

ciel/cahiers/1996-1997.

25. Sablayrolles J.-F. La néologie en français contemporain. Examen $d u$ concept et analyse de productions néologiques récentes. Paris: Honoré Champion, coll. «Lexica», 2000. №4. 589 p.

\section{Information about the author:}

Kosovych O. V.,

Doctor of Philology, Chair,

Professor at the Department of Roman-Germanic Philology, Ternopil Volodymyr Hnatiuk National Pedagogical University 2, M. Kryvonosa str., Ternopil, 46001, Ukraine 